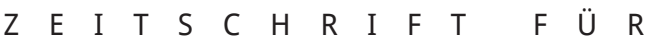

$\begin{array}{lllllllllllllllllllll}V & E & R & W & A & L & T & U & N & G & S & G & E & S & C & H & I & C & H & T & E\end{array}$

$\begin{array}{lllllllll}B & A & N & D & 4 & 2 & 0 & 1 & 9\end{array}$

S E I T

D O I : $10.2478 / \mathrm{ADH}$ I- $2019-0008$

\title{
Paper Affairs: Discipline by the Dossier in a Mao-Era Work Unit
}

\section{J. M. CHRIS CHANG}

Among the varieties of official records that bound together the Maoist bureaucracy, few documents spilled over into the lives of ordinary subjects with the force of the personnel dossier. As the central artifact in the system of individualized records on citizen-employees in Maoist China (1949-1976), the dossier combined the functions of human resources, political surveillance, and administrative discipline into a single comprehensive file that tracked a person year after year. In their documentation of Chinese subjects, dossiers often collapsed the division between the bureaucratic and the social and recast the routines of state surveillance as mediators of everyday social problems.

In this essay, I take a microhistorical approach to the case of an adulterer named Lin Zhongshu to explain how the paper routines of the dossier were entangled with the administration of discipline for petty misconduct. ${ }^{1}$ My analysis follows in the vein of recent case studies on sunknown Maoist China as an alternative point of departure for understanding socialism from below. ${ }^{2}$ The focus of my study, Lin Zhongshu, was a factory worker in Baoding, Hebei, whose comfortable way of life was thrown into turmoil when an extramarital affair came to light in 1974. Before he could be punished, Lin went into hiding for several years as his dossier accumulated evidence of his 'hooligan (liumang) crimes. When Lin finally resurfaced in 1978, the extensive documentation of his misdeeds was enclosed with a petition from his work unit to their head office requesting to »deal with the Lin Zhongshu problem once and for all«.

The content of Lin's dossier file shows bureaucratic research at its most exhaustive, but the case reflects more than the travails of a social troublemaker. In this case study, the production of the file itself is also an object of inquiry, insofar as the dossier sheds light on how bureaucratic approaches to local justice and public order were conditioned and enacted through the paper-based habits of Maoist file-keeping. Drawing upon a wider scholarship on bureaucratic writing and documentation, I explore how the creation of dossier materials played a bureaucratic role in Lin's investigation and discipline. ${ }^{3}$ I trace how Lin's affair was fashioned as a hooligan crime through bureaucratic transactions involving different constituencies and agents, including Lin himself. The paper workflows, evidence trails, written confessions, and official correspondence that constitute the case demonstrate how the pursuit of truth was subordinated to protocol and coordination between the investigators and higher-level authorities. To engage Lisa Gitelman's observation that »bureaucracies do not so much employ documents as they are partly 
constructed by and out of them «, this close reading of a dossier aims to disaggregate Maoist bureaucracy into the agents, actions, and objects engaged in documenting problematic subjects. ${ }^{4}$

I begin by situating the Lin Zhongshu file within the broader development of the dossier system in Maoist China. A brief institutional outline identifies the wider historical forces that factored into Lin's predicament in the 1970s and addresses the issue of why personnel files - as employment records - would play an institutional role in the policing of hooligan crimes. This introduction also aligns the present historical case study with new methodologies and scholarly work on petty offenders from the perspective of 'grassroots history`.

What is officially known as the scadre personnel dossier system Organization Department of the Chinese Communist Party (CCP) during the second Sino-Japanese War (193745). ${ }^{5}$ Modeled after both Soviet and KMT internal files, personnel dossiers in their earliest iteration enabled party administrators to evaluate and assign cadres to new posts while maintaining a permanent record of political liabilities. ${ }^{6}$ After the founding of the People's Republic of China (PRC), the socialist restructuring of economic production led the party-state to vastly expand the use of dossiers beyond party cadres to broader categories of persons. The First Five-Year Plan (1953-1957) precipitated large-scale nationalization and collectivization in industry and agriculture; this process permanently assigned millions of urban citizens to new state enterprises organized by 'work unit`. With the pronouncement of the "Temporary Regulations on Cadre Dossier Work " in 1956, the central authorities issued requirements for all lower administrative bodies to produce personnel files on their employees, to be maintained within the work unit for review or update as necessary. ${ }^{7}$ In the period from 1956 to 1978 identified as "high socialism « by Brown and Johnson, the coverage of personnel dossiers grew to encompass most professions in urban China, including shop clerks, factory foremen, office staff, teachers, railway workers, and merchants. ${ }^{8}$

As dossiers were extended to the urban masses under high socialism, dossier management was absorbed into the human resources operations of the work unit (danwei) as both institutional employer and basic division of socialist governance. ${ }^{9}$ Within the multipurpose structure of the work unit, the dossier was broadened into a general-use record with practical applications in workplace investigation and discipline. Dossier access was restricted to supervisors, and the files themselves were classified as s state secrets . The array of revidentiary materials، (zhengming cailiao) compiled by the dossier - including self-criticisms, witness affidavits, and third-party complaints - informed personnel decisions on positive and negative political labels, as well as rewards and punishments.

Administrative discipline by the work unit was not narrowly concerned with workplace or criminal behavior, but was instead responsible for policing a long list of potential sproblems`, including theft, malingering, 'hooliganism`, and various moral offenses that did not rise to a full legal definition of crime. In such cases, dossiers could be used to validate demotion, relabeling, detention, or curtailing benefits and pay. Dossiers also provided a permanent reserve of evidence if and when the need for disciplinary action against a person arose in the future. sBlack marks dossier severely damaged an individual's livelihood and prospects, and the threat of their inclusion served as a potent mechanism of control. ${ }^{10}$

This implicit disciplinary role makes the dossier an indispensable historical source for understanding crime and punishment in the Mao era, where historically a wide discrepancy existed between the formal prescriptions of the law and the reality of how discipline was handled by local authorities. ${ }^{11}$ Dossiers address an empirical gap by attesting to administrative discipline in action, revealing what crimes were subject to investigation, how crimes were investigated, and who was doing the investigating. But if dossiers are crucial to understanding these marginal practices, they also require the use of a distinct historical methodology with its own conditions and limitations.

The focal point of this case study, Lin Zhongshu's dossier, is one example from a body of historical materials known to the China field as sgrassroots sources`. Previously referred to as 'garbage sources` (laji cailiao) until Jeremy Brown rebranded them in a 2015 "Dissertation Reviews" article, these sgrassroots sources، denote documents, files, and government papers that have been discarded by state archives and work units, and since entered private hands. ${ }^{12}$ 
The field's growing reliance on this type of source is itself a response to barriers to archival access in the PRC, a practical problem of historical research that has intensified over the past decade. In recent years, a group of China scholars - well-represented in two important edited volumes, Brown and Johnson's "Maoism at the Grassroots«, and Leese and Engman's "Victims, Perpetrators, and the Role of Law in Maoist China" - have sought to broaden the possibilities of empirical research by buying up discarded archival sources. ${ }^{13}$ Such documents would have been marked for disposal from overcrowded state holdings after the archival 'great cleansing، started in 1978; however, instead of meeting destruction, a large portion of these documents resurfaced in secondhand book and paper markets where they were bought by researchers and collectors. ${ }^{14}$ In mining this stream of historical material, I engage a growing body of scholarship that utilizes the unique provenance and content of grassroots sources to shed light on historical issues interwoven with the structures of everyday life. ${ }^{15}$

In my case study of Lin Zhongshu, I have sought to extend the ground-up approach of grassroots history as far as the sources will allow. But working at the level of microhistory is not only a pragmatic methodology, it is a means of focusing attention on the labor, materials, and the politics of production related to file-keeping so as to generate insight into the peculiarities and contradictions of Maoist administration. Elsewhere, the dossier system has been theorized as a rdisciplinary institution in a classic Foucauldian sense, invoking a metaphor of production in which the making of a file is commensurate with the construction of legibility and categories of personhood. ${ }^{16}$ However, looking at historical examples of the social practice of dossier work complicates what this production entails. As I show with the case of Lin Zhongshu, the making of a common criminal could be a haphazard bureaucratic process lacking in state knowledge or ideological consistency. Dossiers at the grassroots were instead evocative demonstrations of the local conditions of bureaucratic production, highlighting the variation, friction, and contingency inherent to movements of paper between overworked agents in a decentralized system. Lin Zhongshu's case illustrates how outcomes were often decided less by ideology

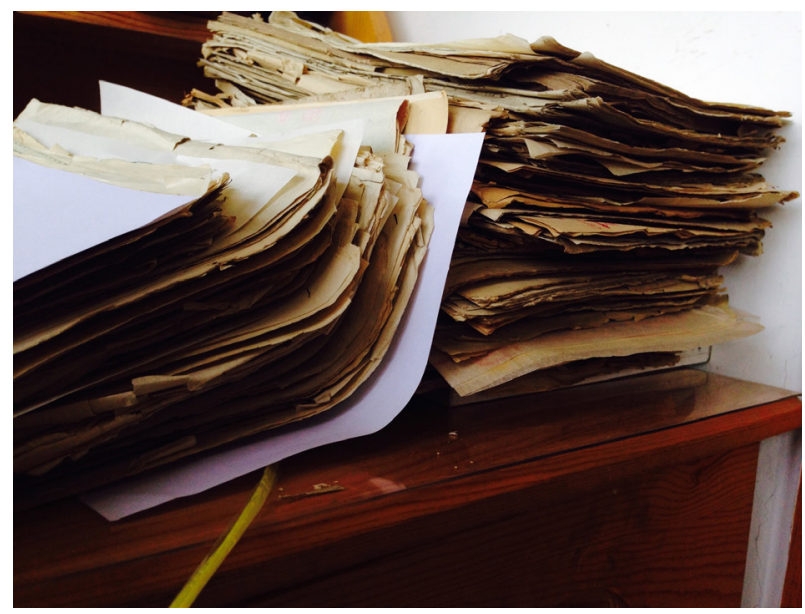

Figure 1: Stack of discarded personnel files. (Source: author's collection).

documentation requirements of reporting upwards, or the written eloquence of the accused in narrating their own culpability. The resulting misunderstandings and indignities that filled Lin Zhongshu's dossier were less indicative of the ineffectiveness of the authorities than the awkward fit between the tools and methods of bureaucratic investigation with respect to the social phenomena they purported to capture. As is often the case with microhistories, in studying dossiers, we often find examples of inversion: dossiers were designed as an apparatus of social control, yet they also became one of the primary mechanisms through which the objectives of Maoist administration became entangled in the mundane, unresolvable problems of everyday social life (Fig. 1).

\section{"A Hooligan of the Worst Kind «: Lin Zhongshu Writes Love Letters}

\author{
Lin Zhongshu; Male; born: 1942; family origin: self- \\ reported urban poor; occupation: day-laborer; \\ political status: of the masses
}

In the autumn of 1976, the death of Mao Zedong and the ensuing fall of the radical 'Gang of Four « brought a final close to the Great Proletarian Cultural Revolution. In the aftermath of Mao's last campaign, the reorganized party leadership was compelled to address a long catalog of historical grievances stemming from the wrongs 
and excesses of the ten-year struggle. This process of collective reckoning took place across all levels and locales, and pursued both rehabilitation for the unjustly accused as well as retribution for unpunished wrongdoers.

It was in this spirit of correcting old wrongs that in April 1978, the No. 3 Engineering Unit of the Hebei Engineering Installation Company dispatched a thick file to their head office regarding a history of misconduct by one of their employees, a 36-year-old man named Lin Zhongshu. ${ }^{17}$ The No. 3 Engineering Unit, which as Lin's work unit technically still employed him, branded Lin as a "hooligan of the worst kind" alleging in a summary report:

Lin Zhongshu has been absent from work, has violated the labor regulations and commits all kinds of petty crime. In previous times our work unit was not in a position to handle his behavior, but he has had a negative impact on the general public and his influence is extremely bad. He has hindered our progress in many ways.

The summary report went on to detail a litany of offenses committed during Lin's tenure at the company from 1967 to 1978, including malingering, petty theft, fraud, and adultery. ${ }^{18}$ In response to his behavior, the No. 3 Engineering Unit had attempted at various times to detain or re-educate him, but due to a confluence of circumstances, Lin evaded substantial punishment and even remained on the factory payroll as of 1978. In an effort to bring final resolution to the case, the No. 3 Engineering Unit requested in their summary that the head office approve the harshest possible sanctions for Lin, along with expulsion from the work unit.

To ensure a favorable decision, the Third Engineering Unit took the additional step of enclosing with their request the supplemental appendix (fujian) of Lin Zhongshu's dossier, containing all evidence of his misdeeds over the past ten years. The evidence alone in Lin's case spanned more than 200 pages, containing confessions, accusations, background checks, and a large tranche of love letters proving Lin's extramarital affair. The seized letters constituted about half of the file and had been processed into a documentary exhibit in their own section. It was on the basis of this evidence that the head office of Hebei Installation Engineering Co. would pass judgment on Lin Zhongshu's shooligan crimes` and determine if he should be brought to account. ${ }^{19}$

As the appended materials came directly from Lin's dossier, they formed a portrait of Lin's adult life as well as a record of the investigative practices of his work unit over that period. According to the file, Lin Zhongshu was first assigned to work at the No. 3 Engineering Unit's factory as an apprentice in June 1967. He was soon promoted to crane operator and drew a comfortable salary and benefits. However, from 1967 to 1978, Lin's total number of work days amounted to less than three years. Most of those working days were concentrated between 1967 and 1969. After that period, Lin appeared at the factory only sporadically, often coinciding with days when the factory distributed uniforms or winter supplies. For most of the 1970s, Lin was absent for long periods and lived off of sick pay. When the factory officials attempted to cut him off, Lin resorted to "bringing in people from outside the plant to make a scene « and strong-arming the officials into signing his documents. The file named a certain ruffian from the No. 1 Rubber and Plastics Company who backed Lin on these occasions.

The year 1974 was when Lin's 'hooligan activities came to a head. Of the evidence that would later enter Lin's file, the bulk of the material was produced in 1974 immediately following the explosive revelation of an extramarital affair. In the Mao era, 'hooliganism، (liumang) was an ambiguous label that was commonly applied to a range of negative personal behaviors associated with sexual deviancy. 'Hooliganism disciplinary context encompassed explicit crimes as well as acts bordering on the edges of criminality, inclusive of sexual assault, homosexuality, seduction, adultery, and prostitution. ${ }^{20}$ These offenses were not considered "counter-revolutionary" by definition, though they were often attributed to low political consciousness. However, as explained in Yang Kuisong's microhistory of Zang Qiren, a man criminalized in the 1970s for his homosexuality, 'hooligans` were viewed as a subset of sbad elements` who caused harm to socialism and therefore necessitated firm discipline. ${ }^{21}$

It should be noted that in Lin Zhongshu's case similar to the circumstances of Zang Qiren - his work unit took action against him in response to what was 
viewed as an immoral sexual relationship. According to the legal framework of the PRC at the time, adultery was not prohibited by formal statute; on the contrary, legal reformers in 1957 explicitly recommended that fornication and adultery be excluded from criminal prosecution. ${ }^{22}$ However, Lin Zhongshu's case reflects a common tendency among work units in the Mao era to zealously pursue disciplinary investigations into private behavior. ${ }^{23}$ In Lin's case, perhaps to justify an uncommon fixation with a scandalous affair, the investigators sought to frame their extensive research into Lin’s 'hooliganism، as an exposé of his morally and politically degenerate character, rather than seek punishment for the adulterous relationship itself.

According to the exhaustive investigation conducted in the wake of the incident, Lin was 32-years-old in May 1974 when he was introduced to a 23-year-old woman named $\mathrm{Xu}$ Xiufang through a mutual acquaintance. $\mathrm{Xu}$ had just graduated from Hebei Normal University with a degree in education and would soon be starting a job as a teacher. Despite a spotty track record at the factory, Lin was a party member from youth and evidently benefited from political friendships in the city of Baoding. Xu asked for an introduction in the hope that he would be able to use his connections to help her secure a job in a more desirable locale such as the prefectural-level city of Baoding, as opposed to working in the countryside. Lin promised to look into the matter and make some inquiries on her behalf.

Both Lin and Xu were already married, but over the next four months, the two would develop a short-lived, intense relationship. Lin would call on Xu at her sister's house, and later Xu's new school in Wan county, 30 miles outside of Baoding. Though it turned out that Lin was unsuccessful in helping Xu secure a job in the city, he took up a self-appointed role as her political mentor and benefactor while pursuing her romantically. As an urban resident with an enviable proletarian job, Lin had access to coveted consumer goods, such as the new Red Flag Heavyweight bicycle that he promised to $\mathrm{Xu} .{ }^{24}$ Besides the bicycle, Lin claimed in his subsequent confessions that he showered $\mathrm{Xu}$ with gifts of eggs, pulled noodles, persimmons, mooncakes, a flashlight, and a transistor radio belonging to his wife.

Due to their separate circumstances, Lin and Xu's affair consisted largely of a romantic correspondence.
Both were living with their spouses and separated by a six-mile bike ride, but they wrote letters to one another regularly. These letters later became bureaucratic facts when all of their personal correspondence was seized by the authorities. Lin and Xu's love letters were gathered, organized, mined for information, and eventually filed into Lin's dossier as proof of the affair. For a number of years as Lin's case worked its way through the work unit's disciplinary channels, his love letters circulated as a bureaucratic display.

The letters themselves are very ordinary and belie the impression of shooligan a activity. On the contrary, Lin's approach to courtship was to present himself as a steadfast advocate of revolutionary virtues. He frequently addresses Xiufang as stongzhi/comrade` and signs off with sgeming jingli/salute to the revolution،. His attitude to Xiufang is one of paternalistic revolutionary encouragement, writing at one point, »My visit must have tired you out. However, you did not seem to mind, just like a seasoned fighter for the revolution, you are strong and have persevered. You have achieved what a common country girl could not, I am proud of you and admire you «. Elsewhere, Lin reflected on being orphaned at a young age, and his relationships:

"I lived for many years without my father or mother; it was the Party that raised me. I haven't contributed much of anything, but the state and the masses have always looked after me and I am in debt to them. I am in debt to you too-you are always concerned about my health, and health is the foundation of the revolution, without good health and thought, we cannot do good work for the revolution«.

Lastly, Lin spoke of eventualities: "In the not too distant future, we will work together, study together, live and struggle alongside one another".

For her part, Xu wrote many letters as well. Xu's letters are on the whole shorter and less overtly patriotic, if equally affectionate. The correspondence seems to show that the relationship was one of mutual interest, though $\mathrm{Xu}$ expressed a degree of trepidation about being discovered. In response to a comment in one of Lin's letters, she questioned him, "Why are you keeping all of my letters? I wish you would not. They should be thrown out or burned after reading." Her concerns 


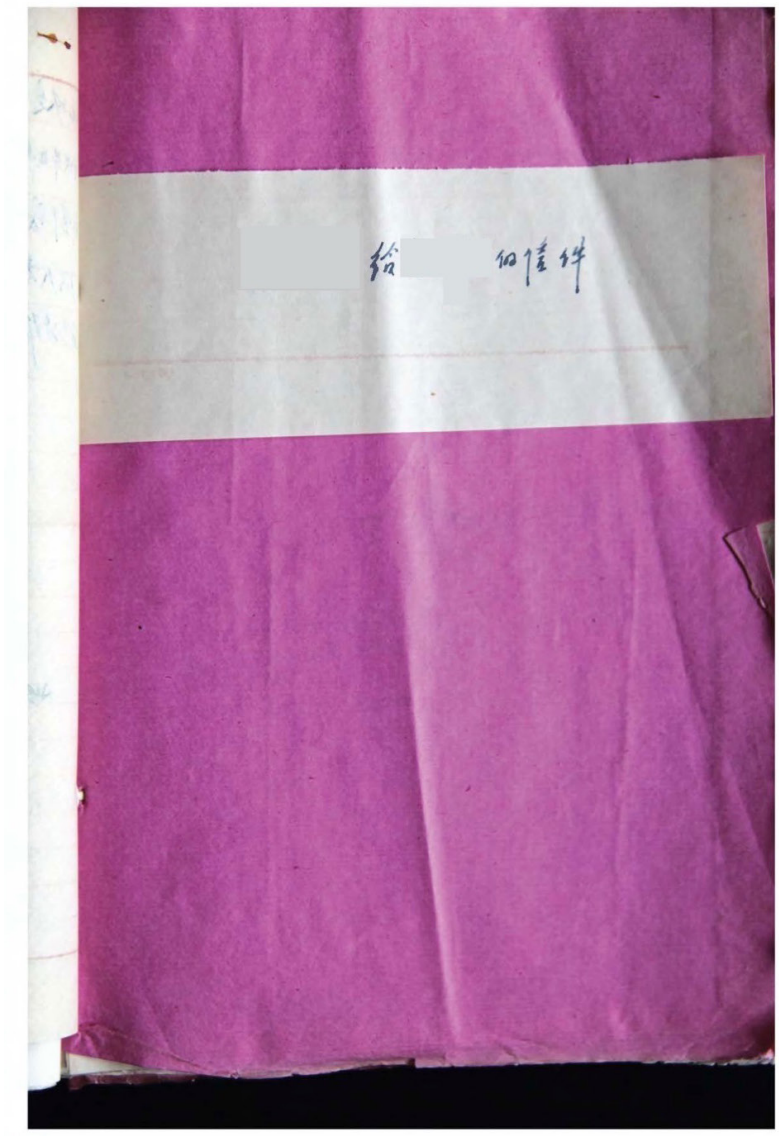

Figure 2: Love letters as evidence. (Source: author's collection).

fell on deaf ears, as Lin would respond with homilies such as, "Difficulties will not discourage heroes, dawn will come soon; all you are doing is embracing the deep emotions of the proletariat«.

Even by the uneven standards of Mao era personnel investigation, the preservation of the letters in Lin's dossier was peculiar. The filing of the letters appeared to involve an element of archival misrecognition. On the one hand, dossiers were often filled with genres of epistolary writing. Most of the time, these letters entered into the category of sevidentiary materials`, as sworn affidavits by third-parties corroborating or refuting a subject's version of events. Lin's love letters passed the test visually: they were comprised of handwritten texts that seamlessly integrated themselves into the dossier's corpus of witness statements and affidavits, testifying to

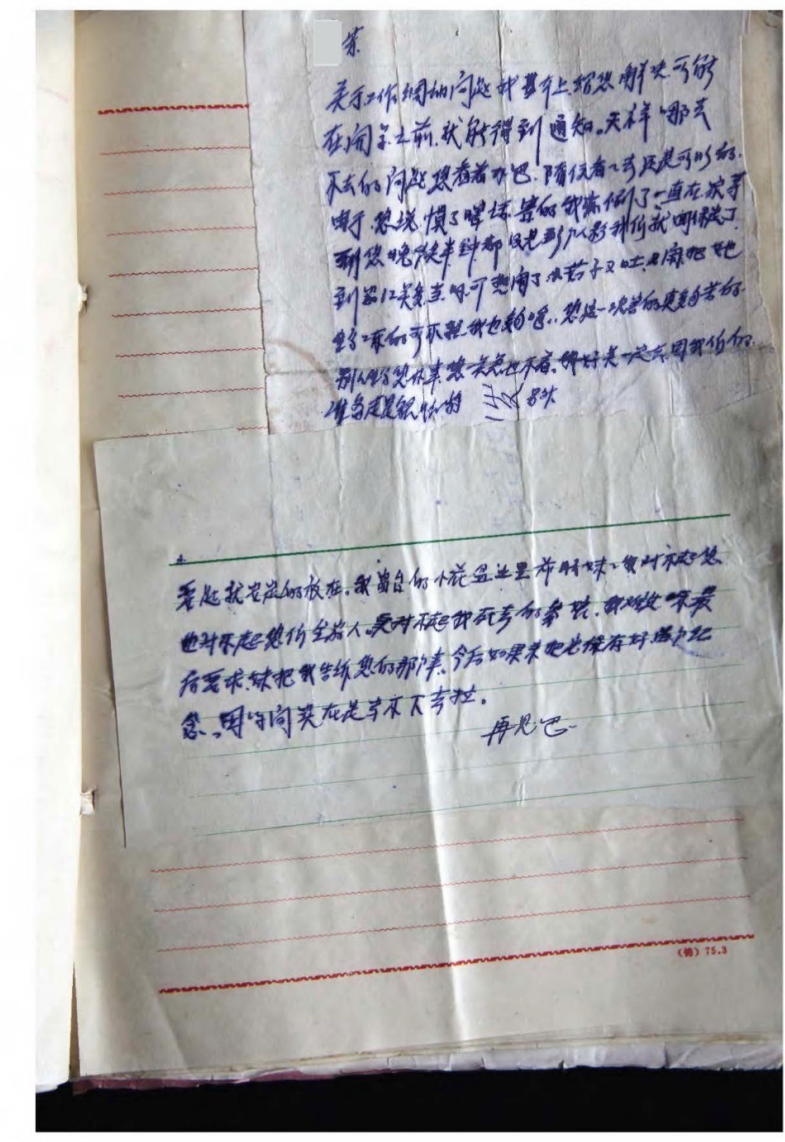

which conveniently for the investigators took a textual form. In other words, the letters were not typical sevidentiary materials produced by the investigation as supporting documents; they were the historical objects of the affair itself and were exhibited in Lin's dossier as physical proof of his wrongdoing (Fig. 2).

The anonymous administrator who handled Lin's correspondence invested a high level of thought and care into its preservation as a documentary exhibit. All of Lin and Xu's letters were collected, inventoried, and arranged by date. Many of Lin's letters were written on decent stationery bearing the office letterhead of Lin's wife. But Xu's letters were often written on odd-size bits and pieces of paper. As with any material designated for the dossier, these scraps had to be trimmed and resized, and then mounted with a wheat paste onto regularsized pages to fit the dossier without obscuring any of the original text. Letters of more than one page were numbered by the administrator on the top-right corner 
to note that they were part of a set. At some point in the process, some reader studied all of the letters and underlined key passages or sections to support the allegations in the report. ${ }^{25}$ This could not have been an enviable task, and yet this tedious presentation captured an essential part of what day-to-day dossier work consisted of.

For Lin and $\mathrm{Xu}$, romance devolved into crisis in November 1974 when Lin's wife, Ma Junqing, directed a complaint to Xu's work unit. Ma Junqing had apparently discovered some of the personal correspondence which confirmed her existing suspicions about the nature of the relationship. She wrote to the leadership of Qiming Village Middle School, where Xu was employed as a physical education teacher, requesting that they discipline $\mathrm{Xu}$ :

Party Branch and Revolutionary Committee Members:

Greetings. There is an issue I wish to raise regarding the relationship between Teacher $\mathrm{Xu}$ who is employed by your school and my husband, Lin. I had heard of multiple rumors floating around that they were in a relationship. They both denied it, and I chose not to pursue. Xu often comes to Baoding. Since I often stay with my mother, when Xu visits, she stays at my house alone with Lin sometimes for days. She plays my husband against me, therefore my relationship with my husband is terrible. She writes to my husband frequently, and in one letter she said: "Our journey together is turbulent, yet the future is bright and sweet " -Why is she writing such a letter?

Needless to say, Lin bears responsibility for this situation, but so does $\mathrm{Xu}$. Although she is a young person in the New China, I feel she must be of the lowest quality to compose such an embarrassing letter. How can a teacher have such corrupt virtues? $I$ request the leadership of the school to educate $\mathrm{Xu}$ and assist her in avoiding such serious mistakes in the future.

Ma Junqing

[1974]-11-25
(PSB). This assumed that the affair could be dealt with as a personnel matter with the work unit acting as the relevant disciplinary authority. ${ }^{26}$ The school's response was swift. Within three days, they had interviewed $\mathrm{Xu}$ and sent a request to Lin to have him visit the school for a face-to-face talk with school leadership. Lin complied with the request and traveled out to Qiming village to attempt to clear up the situation. But upon arriving in Qiming on the appointed day, Lin was confronted by a group of locals and >militiar who had blamed Lin for "seduction", and had assembled to protect Xu's reputation. In lieu of the serious sit-down with school leadership, Lin received a physical beating for his perceived culpability in initiating the affair. The group detained Lin overnight and handed him over to the Public Security branch of Wan County the next day.

Initially, the parties to the affair had sought to keep the PSB out of the matter, but Lin's arrival in Qiming had caused a small civil disturbance, so the Wan County PSB took him into their custody. In order for the PSB officers to file a full report, they required a detailed account from Lin of the complete set of circumstances that led to his beating in Qiming village. In Wan county, Lin would write the first of no fewer than seven sselfexaminations، admitting to the affair. Lin would later claim that he wrote this initial confession under duress. For reasons that are unexplained, this initial confession is the only version that is absent from Lin's dossier - all others were filed in the dossier as original documents.

For the next month, Lin shuffled through interdepartmental purgatory as one organ after another passed off responsibility for dealing with him. Having obtained the required confession, the Wan County PSB sent word to the Baoding Municipal PSB that a certain Lin Zhongshu of their jurisdiction was in their custody. Lin was handed off to the $8^{\text {th }}$ Precinct of the Baoding PSB. However, the Baoding PSB also lacked any reason to hold Lin, so after a round of questioning, they notified Lin's work unit to send a representative to pick him up. Back at the No. 3 Engineering Unit, Lin's superiors sent Lin to a local detention center, a type of facility used by large work units as a temporary prison, where Lin entered a sstudy course، under the guidance of one Meng Laoshi (Teacher Meng). The purpose of Lin’s ıstudy course` was twofold. The greater, stated purpose was undoubtedly to re-educate and disabuse Lin of the shooligan` mindset 
that had led to the affair in the first place. The more immediate and pressing objective was to extract from Lin an ideologically passable confession statement that addressed both the facts of the case and struck convincing notes of contrition. Such a confession was a literal prerequisite to close the case and for Lin to be granted release. Meng Laoshi was only a teacher in the honorific sense, and it was clear from the dossier that he was a correctional officer tasked with overseeing Lin's re-education. Thus began for Lin a month of continuous confession-writing under the guidance of Meng Laoshi.

\section{Evidence in Multiples: Lin Zhongshu Writes Confessions}

Lin Zhongshu's case of 'hooliganism ‘ demonstrates how the work unit's discretion over disciplinary matters expanded the scope of personnel files to document political errors and moral peccadilloes. At the same time, documentation did more than preserve a record of personnel investigation within the work unit; investigation materials were forwarded upwards to seek approval from higher level party committees and validate work performed. In many instances, the use of the dossier materials as a reporting device intensified the tendency of local work units to fashion elaborate paper trails in minor disciplinary cases. More generally, reporting upwards also encouraged a style of documentation in which quantities of evidence and formal presentation took precedence over factual content.

Upward reporting reflected the practical tension between the imperative to carry out an investigation thoroughly versus the political pressure to produce file-based deliverables. The incentive structure of the party-state hierarchy was such that the production of deliverables generally took precedence. In any work unit investigation, the findings of the case were subject to review by the next highest party committee or supervising agency - in Lin's case, the head office of the Hebei Installation Engineering Company at the municipal level. Higher level review entailed the implicit threat of sanctions against local administrators for ethical laxity or low-quality investigations. Cases that did not meet standards of rigor were liable to be sent back down for reinvestigation.
Reporting requirements brought about a bureaucratic fetishization of evidence with perverse effects for all parties to the disciplinary process-accused, inquisitor, and higher-level officials. Reporting upward placed intense political pressure on the work unit investigators to rehearse the rigor of their investigative practices, which was most easily demonstrated by sheer quantities of written evidence. Energy and resources were expended on the preparation of appendices to ensure that the finished product contained the right documents, formatted according to proper conventions, in sufficient volume. At the same time, it was unfeasible for the supervisory body to verify all the evidence provided or analyze the materials closely. In gaming approvals, quantity mattered, as did proper formatting and technicalities. Cases may have been more likely to be rejected over formatting than issues of content for the simple reason that a supervisor was unlikely to notice granular inconsistencies across confessions or witness affidavits; however, prohibited formatting such as confessions on red-lined paper or written in ballpoint pen would have been immediately flagged and sent back.

In Lin Zhongshu's case, one piece of documentation was elusive but non-negotiable: the confession statement. A constant principle across disciplinary institutions in the PRC was an administrative insistence on obtaining ssincere confessions from the guilty party for offenses ranging from the severe to the trivial. The criminal system of the PRC, like its Qing and Republican predecessors, promised a measure of leniency to wrongdoers who had fully confessed and appealed to the Party for guidance in reform. ${ }^{27}$ But an equally vital principle in the administration of justice held that obtaining a confession from the accused was an all but necessary condition for administrative resolution..$^{28}$ As disciplinary decisions stemming from county committees to local work units traveled upward for review, confessions were an important means of signaling to the higher levels that an investigation had been carried out correctly, and justice rendered. Cases lacking a full and sincere confession from the guilty party were seen to be empirically, if not procedurally, incomplete.

Within these bureaucratic constraints, taking confessions involved a degree of cynicism on the part 
of the authorities. For an administrator tasked with discipline, the confessant's statement had to satisfy a subjective standard of sincere performance or it would be met with rejection and the confessant would have to try anew. As confessions were generally written at a point in the disciplinary process when guilt had already been determined, the factual content of a confession was a lesser criterion. Besides compliance with formatting specifications, the most important requirement of the confession was its depth of contrition for the appropriate crime, which signaled to the higher levels that the subject had not only been caught but also ideologically reformed - that is, cured of the retrograde ideology that motivated the crime in the first place.

For this reason, in any given case of discipline, a large portion of dossier material reflected repeated attempts to get the confession sright . The rejected versions of the confession, which could be factually at odds with the final version, were filed in the dossier as supplemental material. Sometimes, though not always, the rejected confessions bore comments from the administrator specifying the reason for rejection.

As previously noted, Lin Zhongshu's supplemental dossier file contains no less than six full or partial 'confessions`, five of which were rejected on various grounds. The first of these confessions runs 42 handwritten pages. It recounts the entirety of the affair with an almost implausible level of factual detail, and for its length and comprehensiveness, might be considered an auto-ethnography:

The next morning after dawn, Xiufang did a favor for the head teacher and went to go bake some bing [flatbread] in the morning, as there was only one chef on duty. She helped out for two or so hours, and came back after eleven o'clock with a few bing and some groceries. We ate together. Afterwards, because Xiufang's uncle had taken sick, we went to go get some other things for him, including two pounds of white sugar from the market, and by that time it was already two o'clock. The next day was a Sunday, I took her back to her workplace. Qiming is about $18 \mathrm{li}$ from Nanlu, Xiufang's native village - it's all out in the countryside. ${ }^{29}$ We walked and talked the whole time. Xiufang couldn't believe that I had trekked out this way just to see her and send her off to her work. She felt indebted, and said that she was resolved that we should be deep lifelong friends.

Lin's first confession was summarily rejected. It was so extensive and laden with information that even if it was an accurate record of events, its content was overwhelmed by details of Lin's comings and goings, his consumption of ordinary goods, and frequent trips to the market. Indeed, Lin recounted his extramarital affair primarily through description of his meals with Xu Xiufang - when they ate, what they ate, and sometimes the cost of various items. On page 42 , the long confession came to an end with Lin promising to "deeply examine his problems « with an attitude of "seeking truth from facts", but even this gesture was a questionable application of the Maoist slogan. All 42 pages of this first failed attempt were filed in the dossier.

From December 1974 to January 1975, Lin would try several more attempts at a confession statement. In another rejected confession, Lin, choosing a defiant tone, claimed he had been seduced and listed item by item all the gifts that he had given to $\mathrm{Xu}$, such as food staples, sweets, and electronics. A few days later, Lin made another attempt in which he admitted at least some measure of responsibility:

"Due to capitalist thought playing tricks on my brain, I took to the path of committing crimes and adultery. Since she wrote me many times expressing that we should be together, I replied several times with the same. Because I didn't think of the long-term consequences, things have really gotten out of hand."

Later in his detention, Lin addressed one confession to his overseer, Meng Laoshi specifically:

"Ever since the [beginning of this month], thinking back on my mistakes, my mind has been unsettled, and I am filled with regrets [...] It seems that I did not listen to the Party or to the words of Chairman Mao, and I do not deserve Meng Laoshi's just admonishments. " (Fig. 3)

After several more drafts and a month of detention, Lin finally mustered a passable confession: 

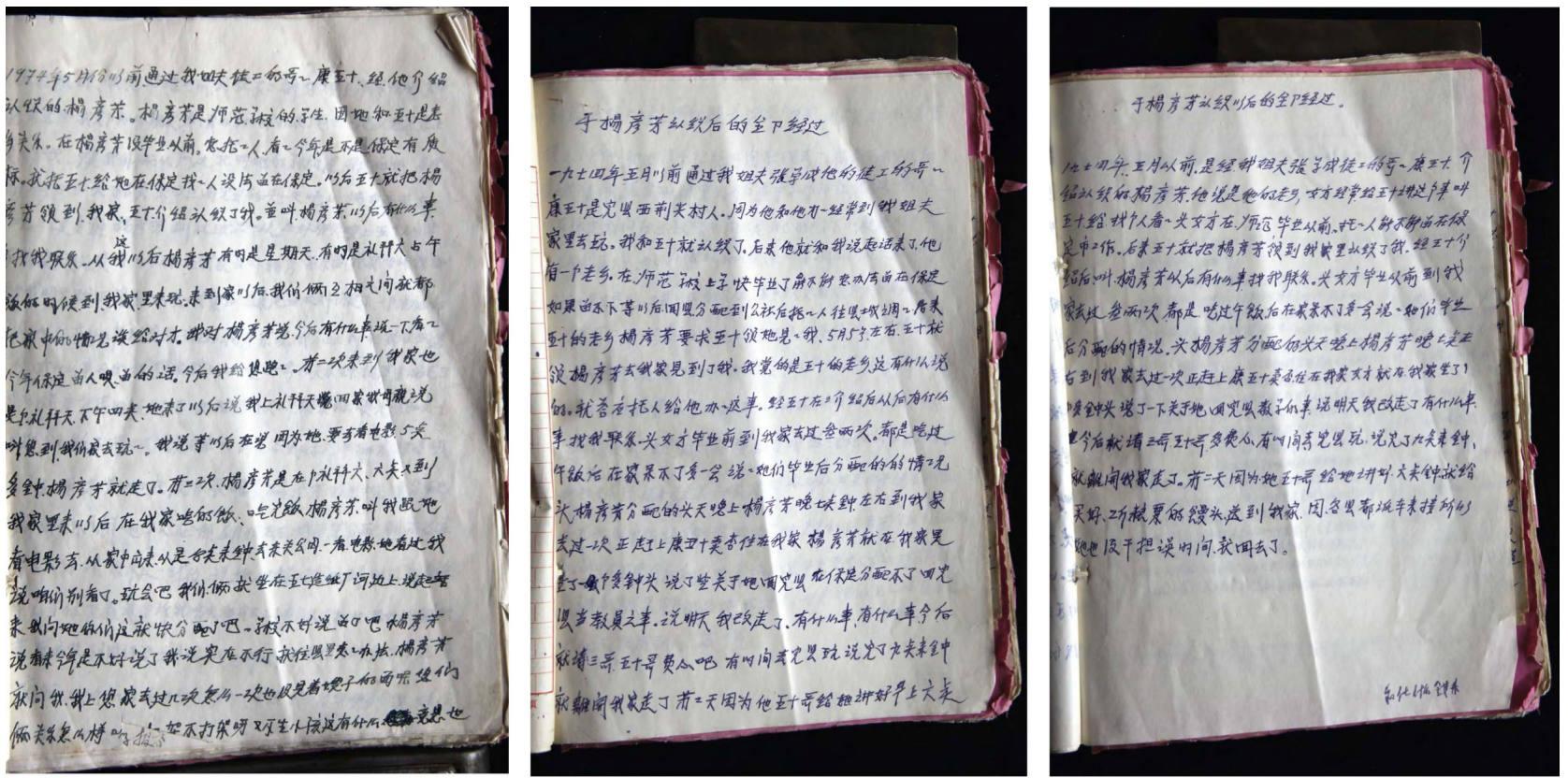

Figure 3: Rejected confessions. (Source: author's collection).

Ever since I committed the act of adultery, leadership and my comrades have found precious time during their busy day to help me to deeply acknowledge my problems, which has completely changed my view of the world, and eased my personal burden. This deep acknowledgement - my heartfelt and honest confession of my problems - will allow me to return to the ranks of the working class, and do even greater things in my work and study. Though I have confessed my problems, my awareness is but superficial. I hope that under the help of leadership, and with my own earnest efforts, I will know my problems and deeply examine myself. I will hold to the attitude of becoming a new person; in my efforts from today forward, I will reform my thought, and from new thought I will recognize my mistakes and use my own revolutionary actions to repay the care and assistance shown to me by the Party and the People.

Lin's last confession is such a departure in tone and content that it reads as though it was written by another person. Yet this example, like the previous six, was written in his own handwriting with the same paper and pen. The auto-ethnographic tendencies of his first confession had been entirely expunged, and the matter of his affair abstracted to the category of the offense and no more. Most striking was Lin's newfound sense of political humility, his performative expression of submission to the wisdom and mentorship of the Party.

Lin's political epiphany defied a simple explanation. Returning to the literature on confessional practices in the Soviet Union, Sheila Fitzpatrick has pointed out that scholarly approaches to citizen confessions have a general tendency to bifurcate these discursive acts into scynicalı vs. ssincere performances. Viewed through that dichotomy, Lin's confession may have reflected a strategic use of political discourse to escape detention or conversely, Lin's writing of six successive confessions reflected a disciplinary process through which Lin internalized the language of a revolutionary subject. ${ }^{30}$ But here I concur with Fitzpatrick's critique that the balance of these interpretations is a false dichotomy of belief vs. non-belief, even as our historical tools give us no purchase on the interiority of the confessant.

Instead we might consider the politics of production that surrounded the confession itself. If a full, sincere confession was a prerequisite for a disciplinary decision to receive approval from the reviewing party committee, the burden of this requirement fell upon both the person accused of the crime as well as the administrator of the 
investigation. In the context of the Cultural Revolution or any political campaign, no official wanted to be viewed as soft on social discipline. If a confession was found lacking, the blame would fall upon the accused as well as the administrator, meaning the latter had a significant stake in the quality of the confession. In this act of confession writing, there existed a certain degree of mutual interest and co-dependence between the confessant and the inquisitor.

In other words, no one had more invested in Lin's political reeducation than the official charged with overseeing his case - the aforementioned Meng Laoshi. By default, every confession was a co-authored production, submitted by a suspect individual under the de facto sponsorship of a bureaucratic guide. ${ }^{31}$ When the confessant failed to perform to standards, the failure was shared between the author and sponsor. In the process, the confession statement, a medium of documentation intended to give closure to the bureaucratic process and peace of mind for superiors, had a way of holding all its participants hostage until the formal standards of the process had been fully satisfied.

The surplus of confessions in the Lin Zhongshu's case indicates the extent to which documenting the rigor of the investigation eclipsed the facts of the case itself. In a parallel to the Chinese context, Katherine Verdery has observed that file surveillance by the Romanian Securitate was motivated by a "performative dimension" in which "political imperatives pushed officers to demonstrate how hard they were working and the revelation of sfacts toward politically predetermined ends. ${ }^{32}$ This official performance of 'facts` as ‘work ‘ mirrors Lisa Gitelman's interest in the document as an epistemic object whose materiality enables its social use as revidence ${ }^{33}$ Dossiers and their contents are classic embodiments of the sknow-shows function of documents. The political pressure to show work in the Maoist bureaucracy required the use of the dossier as a token of knowledge to enable social transactions within the organizational hierarchy.

The denouement of Lin's detention showed that the hostage metaphor for confession writing held a grain of truth. Following Lin's seventh and final confession, Meng Laoshi permitted Lin to leave the detention center and briefly return home for the Spring Festival. The jailers likely took time off as well. Lin took advantage of his window of freedom and never reported back to continue his study course.

For the next four years, Lin lived largely out of the view of the authorities, living off of the help of his sister and a side career of petty theft and swindling. Soon after he disappeared, Lin was accused by a former coworker of stealing a chicken, an electric kettle, and a valuable toon tree. ${ }^{34} \mathrm{He}$ later borrowed a number of small loans from neighbors with promises to help them buy household goods such as charcoal, but never repaid them. The mounting accusations found their way into Lin's dossier in absentia.

In 1978 with the Cultural Revolution over, Lin suddenly turned up again at the factory. Perhaps hoping that the end of the Cultural Revolution and ensuing wave of rehabilitations might offer him a second chance, he requested to have his old job back, in addition to three years' back pay. Management was outraged. Returning to the beginning of our narrative, this was the point at which the administrators of the No. 3 Engineering Unit gathered the hundreds of pages of incriminating material from Lin's dossier and dispatched it to the head office with their request for Lin's immediate expulsion. In explaining the situation, the summary report stated:

[In previous times], due to the influence of Lin Biao and the Gang of Four, our management had no choice but to give in to [Lin Zhongshu's] demands [...] But Chairman Hua has destroyed the Gang of Four, so the conditions for resolving the problem of Lin Zhongshu have come to fruition. ${ }^{35}$ Now under the leadership of Chairman Hua, and guided by the strategic rulings of the Party and the policies of the $5^{\text {th }}$ People's Congress, everyone is working together and struggling toward a new era. Our unit, to catch up with the times, and reflect the changed situation, has reviewed all of our old disciplinary cases and request to resolve this problem of Lin Zhongshu immediately.

Shortly afterwards, the work unit received a reply from the upper levels. Despite several allegations of petty thievery, an extremely well-documented extramarital affair, and a poor reputation at work, the higher-ups refused to grant the motion to terminate. The reply stipulated in terse language: 
Decision: This material cannot be approved! We require: 1) A self-examination for all crimes, with acknowledgement of their severity and contrition; 2) Evidence for hooligan behavior, cheating and stealing; 3) The opinions of the masses

[...] Further, sself-examinations, cannot be written using ball-point pen!

\section{Conclusion: Casualties of the Archive}

Lin's paper trail arrives at an end here. We have no means of knowing what became of him or whether he was ever brought to account for his petty crimes. It is possible that the rejection of the work unit's request for expulsion only provided a temporary reprieve, and that some time thereafter, the delayed hand of justice caught up with Lin Zhongshu. However, there was also a chance that the post-1978 wave of reversals regarding sunjust, false, and mistaken cases` may have cast Lin’s predicament in a sympathetic light, perhaps even opening a path to rehabilitation. In the latter scenario, Lin would have been spared from certain punishment by outlasting his bureaucratic counterparts, who were limited by political protocol and the deliberate pace of paper.

We have a clearer understanding of the post1978 itinerary of Lin's dossier materials than of Lin Zhongshu the person. Lin's dossier exited the archive in the sgreat cleansing، of the 1980s, which commenced alongside the collective reckoning that followed the Cultural Revolution and reform after Mao. Reflecting the state-wide initiative to address historical wrongs, the Central Organization Department in 1980 issued a comprehensive order to "clean out " the contents of cadre dossiers. According to the architects of the plan, the "influence of Lin Biao and the Gang of Four" in the Cultural Revolution had contaminated the dossier system with a deluge of dubious materials:

For every cadre under investigation‘, there were dozens, hundreds, and even thousands of pages of materials [...] Most of these evidentiary materials contained exaggerations, false accusations, and superfluous duplicates. Only a small number of the materials are historically accurate and can be referenced in cadre examinations or studied for the history of the revolution. ${ }^{36}$

The Organization Department laid out instructions for all party-state agencies to purge their personnel records of questionable materials. The general principle of ssorting out dossiers was that for any case that had been overturned, the dossier should retain all records of administrative decisions, such as sentencing decisions, approvals from leadership, and notices on arrest or detention. However, most of the evidentiary materials in the supplemental file were designated to be returned to the individual. This included the return of all self-examinations and confessions, accusations by third-parties, as well as any personal letters, writings, reference material, photos, or notes.

In spite of these intentions, the restitution of dossier materials would be complicated by the same institutional dynamics that plagued local dossier management throughout the Mao era. The Organization Department made the return of materials part of its internal process of cadre rehabilitation, swiftly addressing most highlevel cases by the mid-1980s. But as directives for sorting out the personnel dossiers reached down to the local work units, the return of dossier materials was far from guaranteed. There were many potential issues: the designated recipients for the materials had moved away or could not be located; originals and duplicates could not be fully accounted for; sorting the materials took more time and manpower than the personnel departments could afford. Under these conditions, many local work units assessed their archive rooms and concluded the superfluous dossiers were only fit for disposal. In the ensuing 'great cleansing`, hundreds of thousands of dossiers from the entire span of the Mao era were discarded by local work units or sold as scrap. A few of the materials purged in this fashion, including Lin Zhongshu's supplemental file, eventually found an afterlife as grassroots sources, where they gained a new and different readership (Fig. 4).

With respect to the discarded materials, their dramatic fall from sstate secretı to worthless pulp would have seemed inconceivable to much of the population, but less so to the administrators who had handled the files and were familiar with their content. Since the establishment of the dossier system, mass surveillance had been 


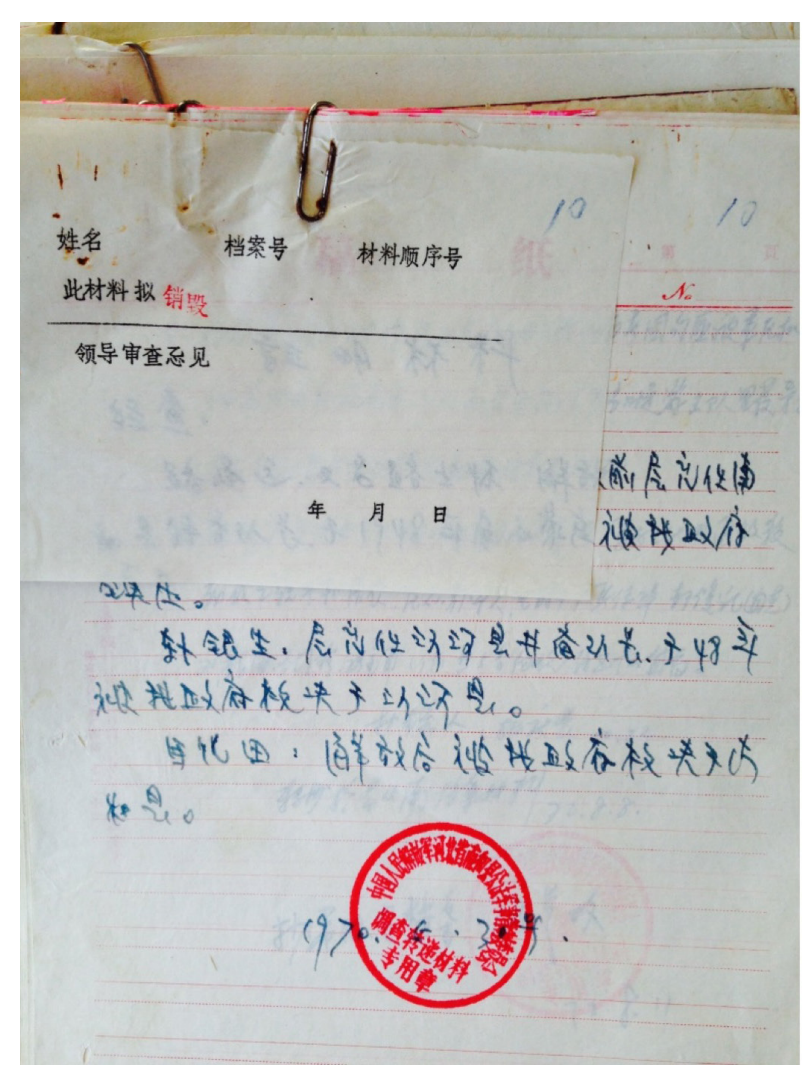

Figure 4: Order for destruction. (Source: author's collection).

reliant on exaggerated claims regarding the quality and scope of the files. Lin Zhongshu's file was one of many dossiers disposed because its accumulated contents were inapplicable to the actual needs of governance. Sending so many products of bureaucratic research to the discard pile was partly an acknowledgement that decades of work had produced vast quantities of evidence with no horizon for future use.

But what then did the overflowing files actually contain? This case study has provided one range of possibilities - a significant portion of dossier materials consisted of rumors, complaints, trivia, and hearsay. Indeed, the composition of Lin's dossier reveals how personnel files were liable to consume-and be consumed by - petty everyday affairs. This observation tracks with our understanding of personnel investigations in the work unit, as well as the social status of the subjects of the files themselves. Dossiers were an insistently grassroots production: investigators were managers in the workplace, informants were co-workers and kin, and punishable offenses were often banal. As the investigative and documentary practices of the dossier were imbricated in the micropolitics of the work unit, disciplinary issues were refracted through the personal, parochial interests of the office, the dormitory, or the factory floor.

Lin Zhongshu's hooligan crimes are indicative of many stories that we find in discarded dossiers scandals, swindles, disputes, and liaisons. One of the premises of this case study is that the record reveals bureaucratic habits and preferences as much as it does the subjects of investigation. In Lin's case, the administrators in 1974 and 1978 focused most of their attention on Lin's affair. It would seem that Lin's other crimes - which were more serious according to statute - did not receive the same degree of concern from the authorities as the comings and goings of an illicit relationship. Lin's case is one example, but this observation aligns with Yang Kuisong's study of the sbad element Zang Qiren, in which the authorities investigating Zang's case lost interest in his dubious political background once his homosexual activity was revealed. ${ }^{37}$ In each case, ideological imperatives to discipline may have offered an official pretense for lowlevel bureaucrats to indulge crude interests. Agents of the Maoist state were not above gossip.

In retracing the steps of the dossier system, one is struck by how much bureaucratic labor was expended for the thick description of ordinary people and behaviors. Bureaucratic administrators became ethnographers of private problems, living habits, intimate relationships, and other basic details of everyday life under Maoism. Turning the focus of these case studies toward the figure of the administrator permits some insight into the methods and afflictions of the dossier system as a whole, in which elaborate routines of investigation were often impoverished by the banality of the problems they purported to address.

\section{Acknowledgements}

I thank the editors of this special issue for guiding this piece to publication. Matthew Hull and three anonymous reviewers generously offered suggestions and trenchant criticisms on an earlier draft of the piece, which have greatly helped to refine its arguments. All remaining errors and omissions are solely those of the author. 
1 I have adopted the convention of using a pseudonym for the subject of investigation in my case study, which is now standard practice for work using grassroots sources.

2 >Marginal persons is a term used by Yang Kuisong (citing Kurt Lewin) in Yang's important collection of individual case studies: Yang Kuisong: Bianyuanren de Jishi [A Record of >Marginal< People], Guangdong 2016. I refer to Yang's work at points throughout the text, but the case study approach has also been utilized to great effect in studies of bureaucratic paperwork outside the China context, as in Ben Kafka: The Demon of Writing. Powers and Failures of Paperwork, New York 2012.

3 For an essential review of this literature, see Matthew Hull: Documents and Bureaucracy, in: Annual Review of Anthropology 41 (2012), pp. 251-267.

4 Lisa Gitelman: Paper Knowledge. Toward a Media History of Documents, Durham 2014, p. 5.

5 Dossiers form an important strand in the authoritative treatment on the Yan'an era in Gao Hua: Hong Taiyang Zenyang Qisheng de. Yan'an Zhengfeng Yundong de Lailong Qumai [How the Red Sun Rose. The Origins and Development of the Yan'an Rectification Movement], Hong Kong 2000. I address the historical linkages to the Soviet and KMT filing systems in forthcoming research.

6 Because dossiers were initially reserved for party cadres, they operated in this period as a double-edged accessory of power. Only ranking cadres would have been required to complete the mandatory background forms, self-evaluations, and autobiographies that entered the official record; however, it was also the case that internal surveillance and counter-subversion drove dossier production, such that every political purge from the Yan'an Rectification campaign onwards entailed the close scrutiny of dossier materials.

7 »Temporary Regulations on Cadre Dossier Work (1956)« reprinted in: Hong Jun (ed.): Ganbu Renshi Dang'an Gongzuo Wenxian Xuanji [Selected Documents on Cadre Personnel Dossier Work], Beijing 1994, pp. 441-452.

8 Brown and Johnson see some of the key features of high socialism as "state ownership of property, Party-state fusion, the politicization of everyday life, and a planned economy that privileged urban industry..." in Jeremy Brown / Matthew Johnson (eds.): Maoism At the Grassroots. Everyday Life in China's Era of High Socialism, Cambridge 2015, p. 6.

9 In the Mao era, the work unit provided essential public services such as housing, education, and health care. It regulated access to consumer goods, professional opportunities, and approved matters such as marriage and divorce. Moreover, the work unit was a front-line political organization with responsibility for the good political behavior of its employees: it organized ideological meetings, maintained personnel records, and exercised discretion to discipline individuals for personal or professional transgressions. See Xiaobo Lü / Elizabeth Perry: Danwei. The Changing Chinese Workplace in Historical and Comparative Perspective, Armonk 1997; Victor Shaw: Social Control in China. A Study of Chinese Work Units, Westport 1996.

10 The dossier system was a frequently cited object of popular dissatisfaction. During the Hundred Flowers movement in 1956, criticism of the arbitrary power of the dossier boiled over in a number of forums, including this description by one anonymous critic: "When I arrive at the personnel office, my hair stands up on end with fright. As soon as someone from outside comes through the door, the whole staff scrambles to stuff the files from desks into drawers. Why so secretive? It's as though everyone who comes in has a sproblem< [...] Life, death, freedom, and imprisonment are all in their hands. Their methods are like the police, showing up spontaneously with a small notebook recording your information, always secretive, suspecting everyone«. Anonymous: Rightist Remarks at Wuhan University Attacking Personnel File System (1957), in: Database for the History of Contemporary Chinese Political Movements, online: https://ccrd.usc.cuhk.edu.hk. (1. 6. 2017).

11 Particularly after the termination of what Liu and Chiu have called the PRC's constitutional experiment in 1957, cases of petty, personal crime were increasingly handled outside of juridical courts and instead left to local party committees and work teams. Serious crimes would trigger referral to the Public Security Bureau (PSB), but the work unit policed a host of lesser minor offenses in the grey area between workplace misconduct and crime. Hungdah Chiu / Shao-chuan Leng (eds.): Criminal Justice in Post-Mao China, Albany 1985, p. 13.

12 Jeremy Brown: Finding and Using Grassroots Historical Sources from the Mao Era, in: Dissertation Reviews, online: https:// dissertationreviews.wordpress.com (15. 12. 2010).

13 The essays in Daniel Leese / Puck Engman (eds.): Victims, Perpetrators, and the Role of Law in Maoist China. A Case-Study Approach, Berlin 2018, are notable for examining themes of justice and punishment exclusively through case studies. The present study is conducted in the same spirit.

14 Leese / Engman: Victims, Perpetrators, and the Role of Law, p. 7.

15 Brown / Johnson: Everyday Life Under Maoism, pp. 4-7.

16 See Michael Dutton: Policing and Punishment in China. From Patriarchy to sthe Peoples, Cambridge 1992; also Jie Yang: The Politics of the Dang'an. Spectralization, Spatialization, and Neoliberal Governmentality in China, in: Anthropological Quarterly 84/2 (2011), pp. 507-533.

17 Author's Collection. "Materials on the Lin Zhonghu Problem: Supplement« Baoding City (1978). All cited primary source material is from this file unless otherwise indicated.

18 The context of Lin's case is germane insofar as it roughly coincides with conventional periodization of the Cultural Revolution (19661976). Baoding was in fact one of the epicenters of Cultural Revolution's worker agitation in Hebei Province in 1966-1967. However, it is notable that the politics of the Cultural Revolution remain largely in the background in Lin's Zhonghu's case, or only appear sporadically as a discursive strategy by Lin and his investigators when arguing the morality of his actions. The delinking of political and private temporalities echoes Gail Hershatter's concept of scampaign times in Gail Hershatter: The Gender of Memory. Rural Women and China's Collective Past, Berkeley 2011.

19 The Hebei Installation Engineering Company continues to exist as part of the state-owned Hebei Construction Group, one of the largest companies in the world.

20 Though shooligan most often referred to cases of deviant male offenders, Aminda Smith's important work explains the reformatory system surrounding former prostitutes, who were coded by the authorities as sfemale hooligan` (nü liumang). Aminda Smith: Thought Reform and China's Dangerous Classes, Lanham 2012.

21 Yang Kuisong: How a >Bad Element (eds.): Maoism at the Grassroots, pp. 19-50.

22 Tung Ching-chih: A Discussion of Bigamy and Adultery, in: Faxue 4/36 (1957), pp. 37-38, in: Jerome Cohen: The Criminal Process in the People's Republic of China, 1949-1963, Cambridge 1968, p. 318.

23 Higher-level work teams also generally eschewed the prosecution of adultery when conducting political examinations. Zeng Yanxiu, 
an investigation group leader during the Sufan and the Socialist Education Campaigns, remarked in his memoirs that specialized investigation teams were told »not to bother « with incidents of adultery or other mature relationships "unfit for civil conversation." At most, such matters were to be dealt with by summoning the involved parties for a polite chat and "dispensing a bit of moral education«. Zeng Yanxiu: Shengan Zatan [A Discussion of Cadre Examinations], Changsha 1986, p. 10.

24 The bicycle became a major point of contention in the aftermath of the affair. Lin himself had a coupon which gave him the right to purchase a >Red Flag Heavyweight‘. The bicycle supply company, however, recommended that Lin hold out in order to purchase a sFlying Pigeon،, or a sForever Bicycle،. Ultimately, Lin fronted the money for the Red Flag on Xu's behalf, but the cost of the bike was greater than the sum of money Xu advanced him, and the exposure of the affair prevented Lin from receiving the full sum of what he paid for the bike. Red Flag and Flying Pigeon were made in Tianjin, Forever Bicycle in Shanghai. In the 1970s, there was a popular saying about these brands: »Flying Pigeon is fast, Forever Bicycle lasts, Red Flag isn't bad".

25 For instance, at one point, the bureaucratic reader underlined Lin's boast, "I do not cling to life like some sad bug that fears death «.

26 Denunciations by family members and spouses were among the most common causes of disciplinary cases and form the basis of an interesting comparison with the scholarship on the Soviet Union. A similar history is traced in Sheila Fitzpatrick: Tear Off the Masks! Identity and Imposture in Twentieth-Century Russia, Princeton 2005.

27 The similar emphasis on the confession is widely noted in the legal scholarship, but the historical precedents for these practices is discussed in Klaus Mühlhahn: Criminal Justice in China. A History, Cambridge 2009, p. 50.

28 Wang Haiguang offers a similar analysis of a case in which repeated confessions were required for resolution in Wang Haiguang: A Different Category of Life. The Counter-Revolutionary Case of a Rural Schoolteacher, in: Leese / Engman: Victims, Perpetrators, and the Role of Law, pp. 75-97.

29 One $\mathrm{li}$ is roughly equivalent to about 0.3 miles, so the entire trip would have been close to 5.5 miles, which it seems the couple covered by foot.

30 These two possibilities for reading Lin's statement might be framed in terms of Steven Kotkin's idea of speaking Bolshevik or Jochen Hellbeck's notion of "subjectivizing practices». Stephen Kotkin: Magnetic Mountain. Stalinism as a Civilization, Berkeley 1997; Jochen Hellbeck: Revolution on My Mind. Writing a Diary Under Stalin, Cambridge 2006.

31 Jie Li has written a fascinating entry on poet Nie Gannu's (19031986) »literary inquisition«. Li casts Nie's dossier writing as a coauthored literature fashioned by the subject with the »censor as muse«. Jie Li: „Are Our Drawers Empty?«. Nie Gannu's Dossier Literature, in: Carlos Rojas / Andrea Bachner (eds.): The Oxford Handbook of Modern Chinese Literatures, Oxford 2016.

32 Katherine Verdery: Secrets and Truths. Ethnography in the Archive of Romania's Secret Police, Budapest 2014, pp. 162-163.

33 Gitelman: Paper Knowledge. Toward a Media History of Documents, p. 1.

34 Also known as Chinese mahogany, the toon tree is both an ornamental and medicinal tree commonly found in the northern parts of China.

35 Hua Guofeng (1921-2008) was Mao's hand-picked successor, and briefly the Chairman of the CCP from 1976-1978 after the death of Mao.
36 »Cadre Personnel Dossiers (1980)« reprinted in: J.P. Burns (ed.): Chinese Law and Government 17/116 (1984), p. 125.

37 Yang Kuisong: How a >Bad Element 


\section{Abstract}

This article examines how dossier files informed the handling of personnel misconduct in Chinese work units using an investigation of adultery as a case study. By the Cultural Revolution (1966-1976), the disciplinary functions of the dossier system were an embedded feature of social control in the work unit, partially shifting responsibility for policing petty crime to local administrators. In this case, the revelation of an extramarital relationship in 1974 set off a bureaucratic operation to produce documentary proof of the alleged wrongdoing. The thick case file prepared by the work unit investigators grew to include a tranche of seized love letters, a series of dubious confessions, and detailed bureaucratic reports. The preparation of evidence bound for the dossier demonstrates the extent to which the demands of documentation formed a distinct end of the investigative process, while revealing how people and paper were mobilized to deal with a minor administrative affair.

\section{About the Author}

J.M. Chris Chang is a Mellon Fellow in the Society of Fellows and a Lecturer in East Asian Languages and Cultures at Columbia University. His research focuses on issues of bureaucracy, mass surveillance, and the afterlife of government paper in modern China. His current project is a history of file-keeping and bureaucratic paperwork in the Mao era as examined through the dossier system, the socialist institution of comprehensive personnel files on individual subjects. 